\title{
EVOLUSI KOMIK WAYANG SEBAGAI UPAYA PELESTARIAN CERITA WAYANG ${ }^{1}$
}

\author{
Dhevi EIR Mahelingga \\ (Praktisi Desain Komunikasi Visual)
}

\begin{abstract}
Abstrak: Tulisan ini membahas tentang komik wayang, yakni cerita wayang warisan budaya Indonesia yang sarat unsur klasik dituangkan dalam suatu bentuk budaya pop. Bagaimana cerita adiluhung nan rumit yang biasa dipagelarkan secara megah dengan pakem-pakem tertentu, digubah menjadi bentuk cerita bergambar yang lebih sederhana dan mudah dinikmati. Beserta penyesuaian demi penyesuaian yang selalu mengiringi perjalanan dunia komik dari generasi ke generasi. Hingga bagaimana komik wayang mendapat tempatnya sebagai salah satu upaya para komikusnya untuk melestarikan salah satu bentuk budaya lokal yang diakui dunia internasional.
\end{abstract}

Kata Kunci : Komik, Wayang, Budaya

\section{Dari Wayang ke Komik}

Wayang merupakan bentuk kebudayaan yang tak terpisahkan dari perjalanan bangsa Indonesia. Selayaknya batik, pertunjukkan wayang juga telah diakui dunia internasional dengan dicanangkannya wayang sebagai Masterpiece of Oral and Intangible Heritage of Humanity oleh UNESCO pada tanggal 7 November 2003. Cerita dalam pewayangan umumnya mengambil dari cerita Mahabharata dan Ramayana. Jika dirunut dari sejarahnya, wayang sudah ada sejak zaman Sri Aji Jayabaya, sekitar tahun 860 Masehi. Namun bentuk pagelaran wayang seperti sekarang ini, seperti dikutip dari National Geographic Indonesia (Pujanto, 2009) baru ada sejak abad ke-15 seiring masuknya Islam dan berdirinya Kerajaan Demak (1500-1550), terjadi abstraksi bentuk karena gambar wayang yang ada berbenturan dengan ajaran Islam sehingga Raden Patah yang didukung Sunan Bonang mengubah bentuk wayang. Oleh Sunan Kalijaga dan Raden Patah, wayang dibagi menjadi tiga versi yakni Wayang Kulit, Wayang Orang, dan Wayang Golek. Ketiga jenis wayang tersebut tersebar di tiga penjuru pulau Jawa.

\footnotetext{
${ }^{1}$ Dipublikasikan dalam Prosiding Seminar Nasional Peran Pendidikan Seni Rupa dalam Pelestarian Budaya Lokal, Universitas Negeri Sebelas Maret Surakarta, 2011.
} 


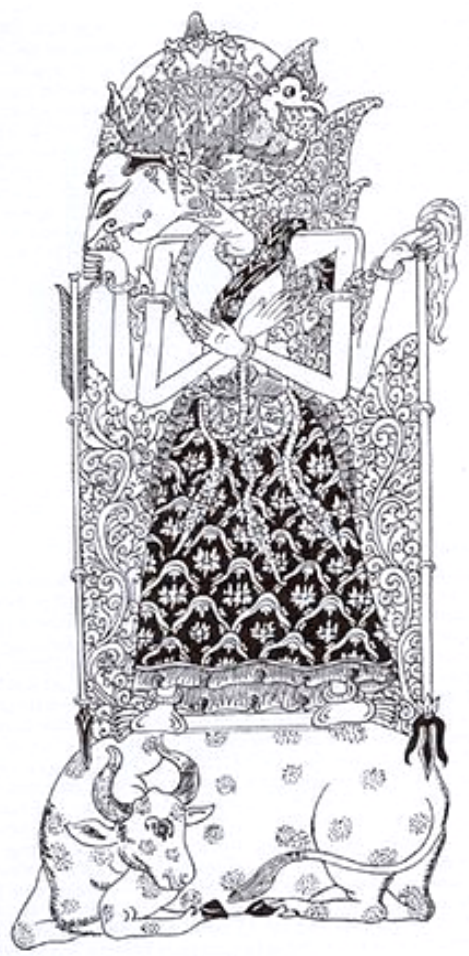

Gambar 1 : Batara Guru (Siwa) dalam bentuk seni wayang Jawa. Sumber : Wikipedia

Pertama Wayang Kulit di Jawa Timur, kedua Wayang Wong atau Wayang Orang di Jawa Tengah, dan ketiga Wayang Golek di Jawa Barat. Masing masing sangat bekaitan satu sama lain. Yaitu "Mana yang Isi (Wayang Wong) dan Mana yang Kulit (Wayang Kulit) harus dicari (Wayang Golek)" (Wikipedia, free encyclopedia). Mengikuti perkembangan jaman, bentuk dari cerita wayang mulai bermacam-macam. Perubahan bentuk itu bukan tanpa sebab, dalam National Geographic Indonesia (Pujanto, 2009) kesenian wayang didaulat UNESCO sebagai World Master Piece of Oral and Intangible Heritage of Humanity juga menghadapi tantangan dalam mempertahankan popularitas dirinya dari masa ke masa.

Tantangan akan popularitas cerita wayang sebenarnya sudah dijawab sejak dulu. Dimulai dengan munculnya gambar wayang di gambar-gambar kartu untuk permainan umbul (permainan dengan memakai gacuk, pemenang adalah yang memiliki jumlah kartu terbanyak dari lawan). Hingga muncul bentuk wayang dalam media komik atau sering disebut komik wayang di tahun 1960-an.

Kesuksesan komik wayang pada era tersebut tak lepas dari nama R.A. Kosasih. Namun, R.A. Kosasih sendiri pada awal karirnya sebagai komikus, tidak langsung menggambar komik dengan latar belakang cerita wayang. Oleh penerbitan tempatnya bekerja, beliau diminta untuk meniru tokoh superhero dari luar negeri yang sudah terkenal untuk diadaptasi dan disesuaikan menjadi tokoh Indonesia.

Kosasih tertarik dengan superhero Wonder Woman terbitan King Feature Syndicate. Kosasih menyulapnya menjadi tokoh Sri Asih. Serial komik Sri Asih dirampungkan sebagai komik pertamanya. Sri Asih dikarakterkan sebagai superhero perempuan berkostum wayang. Memakai kain kebaya dan kemben, rambutnya panjang dengan mata besar, bermahkota giwang dan manik di dahi. Perempuan yang jago 
berkelahi, bertenaga kuat, dan bisa terbang (tokohindonesia.com, ensiklopedi tokoh Indonesia).

Debut pertamanya tersebut sukses hingga menembus angka 3000 eksemplar. Hal itu memacu semangat R.A. Kosasih untuk berkarya secara total di bidang komik. Namun karya yang dihasilkan masih seputar superhero Indonesia adapatasi dari superhero luar yang sudah terkenal. Perubahan besar baru terjadi di tahun 1960-an.

Tahun 1960-an, kondisi politik membuat R.A. Kosasih menghentikan dulu komiknya. Saat itu, PKI melalui Lembaga Kebudayaan Rakyat (Lekra) mengecam komiknya karena dianggap berunsur ke barat-baratan. Tak ayal, tiras komiknya berkurang. Justru yang banyak beredar adalah komik-komik keluaran China (tokohindonesia.com, ensiklopedi tokoh Indonesia).

R.A. Kosasih tidak kehilangan akal, impian masa kecilnya untuk menghadirkan cerita wayang dalam wujud yang lebih singkat tapi tetap berbobot dan disukai banyak orang dituangkan dalam bentuk komik wayang. Dalam sebuah wawancara (Suroto, 2009), R.A. Kosasih mengaku, “Saat itu komik dihujat karena dianggap produk murahan dan berakibat buruk bagi anak-anak. Saya (R.A. Kosasih) tergerak untuk membuat komik cerita rakyat yang berisi pesan moral. Hingga akhirnya saya mencoba membuat komik wayang Burisrawa Merindukan Bulan. Judul itu laku keras dan penerbit Melodie Bandung meminta saya membuat komik wayang cerita panjang dan berseri”.

Komik wayang karya R.A. Kosasih saat itu Mundinglaya Dikusuma, Ganesha Bangun, Burisrawa Gandrung, dan Burisrawa Merindukan Bulan. Terutama Buriswara Gandrung dan Burisrawa Merindukan Bulan, komik wayang tersebut seakan mengobati masyarakat yang haus akan cerita wayang namun jenuh dengan penyampaiannya selama ini, terbukti dari banyaknya eksemplar komik yang terjual. Hingga R.A. Kosasih terpikir kitab Mahabharata yang punya pesan moral dan sudah mengakar dalam budaya Indonesia untuk dituangkan dalam bentuk komik.

Kosasih pun akhirnya membuat komik Ramayana dan Mahabharata. Idenya dari bacaan Bhagawat Gita terjemahan Balai Pusaka. Hasilnya luar biasa. Angka penjualannya mencapat 30 ribu eksemplar. Tiras paling besar sepanjang sejarah komik Indonesia. Dua karya itu memang melambungkan nama Kosasih, namun yang lebih penting lagi, komik 
Mahabbarata berhasil memperkenalkan kisah itu kepada generasi baru, yakni anak-anak dan remaja perkotaan yang jarang nonton wayang kulit atau wayang orang. Bagi mereka, komik Kosasih adalah referensi awal ke kisah klasik asal India itu (tokohindonesia.com, ensiklopedi tokoh Indonesia)

R.A. Kosasih bukanlah komikus pertama negeri Pertiwi. Sebelumnya sudah ada Kho Wan Gie dan Nasroen AS. Karir nya pun sezaman dengan Delsy Sjamsumar, John Lo, Taguan Hardjo, dan Zam Nuldyn. Namun R.A. Kosasih lebih dikenal luas di masyarakat, karena ia mampu menyadur karya sastra kelas berat menjadi komik yang notabene adalah produk pop. Di tangan R.A. Kosasih wayang berhasil divisualisasikan secara sempurna, walau diakuinya ia mencontoh profil wayang orang dan wayang golek. (Suroto, 2009)

Dari paparan di atas bisa disimpulkan, komik wayang terutama karya R.A. Kosasih telah dapat memperkenalkan

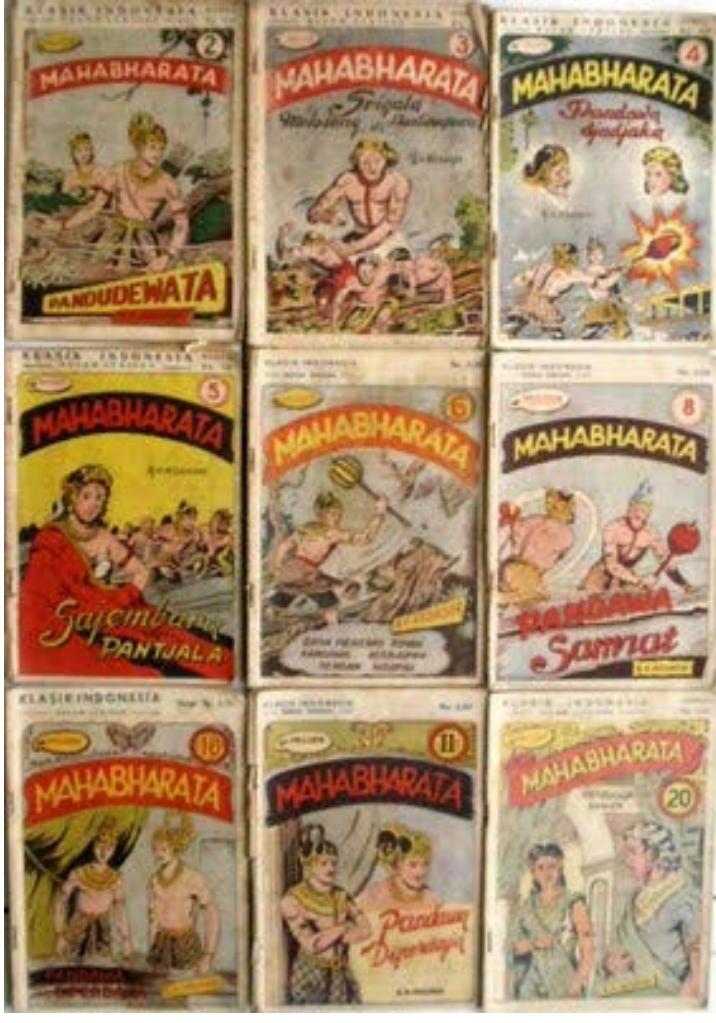

Gambar 2 : Cover komik “Mahabharata” karya R.A. Kosasih kisah wayang kepada generasi muda pada masanya. Angka penjualan yang fenomenal tersebut memberikan semacam angin segar bagi masa depan wayang, dimana kaum muda perkotaan yang tidak tumbuh besar dengan hiburan pagelaran wayang di sekelilingnya, ternyata masih haus akan cerita wayang.

Perubahan jaman yang semakin mengglobal, menuntut kebudayaan tradisional mencari jalan alternatif untuk menyampaikan tongkat estafet pada generasi selanjutnya. Kehausan generasi muda akan jati diri budaya membuatnya tertarik dengan penyampaian yang lebih kreatif dan mendukung kondisi kala itu. Kondisi transisi pergeseran budaya menonton menjadi budaya membaca. 
Bagaimanapun cerita pewayangan yang sarat kaya akan makna, penuh pesan moral, dan media penyampaian pemikiran adiluhung adalah harta warisan yang perlu dijaga dan dilestarikan.

\section{Komik Wayang dan Perkembangannya}

Menurut Serat Centhini, kitab awal abad ke-19 yang dianggap sebagai ensklopedi budaya Jawa yang pertama di dunia-diprakarsai Pangeran Adipati Anom Amangkunegara, kehadiran wayang bermula pada zaman Sri Aji Jayabaya (hingga tahun 860). Karya penguasa Kerajaan Mamenang itu dianggap sebagai tunas Wayang Purwa. Bentuknya masih berupa gambar yang ditorehkan di atas daun tal (rontal atau lontar) dengan lakon diambil dari tradisi lisan (Pujanto, 2009).

Melihat realitas sejarah di atas, tak heran jika sekarang cerita pewayangan kembali bertebaran dalam bentuk gambar, yakni media komik sebagai media berceritanya. Masyarakat pun dapat dengan mudah menerima kehadiran komik wayang, karena bagaimanapun masyarakat Indonesia mengenal komik sudah sejak lama.

Sejarah komik Indonesia dapat ditelusuri sampai ke masa prasejarah. Bukti pertama terdapat pada monumen-monumen keagamaan yang terbuat dari batu (relief). Kemudian lebih dekat dengan masa kini, ada wayang beber dan wayang kulit yang menampilkan tipe penceritaan dengan sarana gambar yang dapat dianggap sebagai cikal bakal komik (Bonneff, 1998:19)

Periodisasi komik wayang bermula sejak 1958, periode yang kita namai komik wayang memberikan warna di antara jenis-jenis yang lain, walau sebenarnya penerbit Keng Po sudah menerbitkan Lahirnya Gatutkaca pada 1954. Sedemikian populernya jenis wayang, sehingga Bahsjar S.J., pelukis dan ilustrator di Medan-kota lain yang memelopori komik Indonesia_juga membuat komik wayang. Komik dari komikus Medan sedikit berbeda dengan perkembangan di Jawa karena biasanya lebih dulu dimuat di harian setempat. Tak mengherankan jika komikus jawara seperti Taguan Hardjo dalam suatu saat mengisi tiga atau empat media setiap harinya (Atmowiloto, 2009).

Pada periode itu, komik wayang mengalami puncak kejayaan. Ada banyak faktor yang membuat komik wayang menjadi begitu laris dengan oplah penjualan melebihi 
komik-komik dengan genre lain. Menurut Arswendo Atmowiloto (Atmowiloto, 2009), komik wayang, juga komik berdasarkan cerita daerah atau legenda, dinilai lebih aman, lebih mendidik, dan yang jelas lebih mengakar. Sehingga tak dikritik, juga tak kena ”bredel”, periode yang terulang keras pada 1966. Karya-karya R.A. Kosasih merajai dalam jumlah dan jilid yang dikeluarkan. Sambung-menyambung menjunjung kisah pewayangan yang tak banyak dikenal masyarakat non-Jawa.

Selanjutnya komik wayang sama seperti komik dengan genre lainnya, mengalami perjalanan mengikuti perkembangan jaman. Komik wayang juga mengalami pasang surut dan dengan berbagai perubahan - atau secara halus disebut penyesuaian - oleh penerbit dengan keinginan pasar sebagai patokan utamanya.

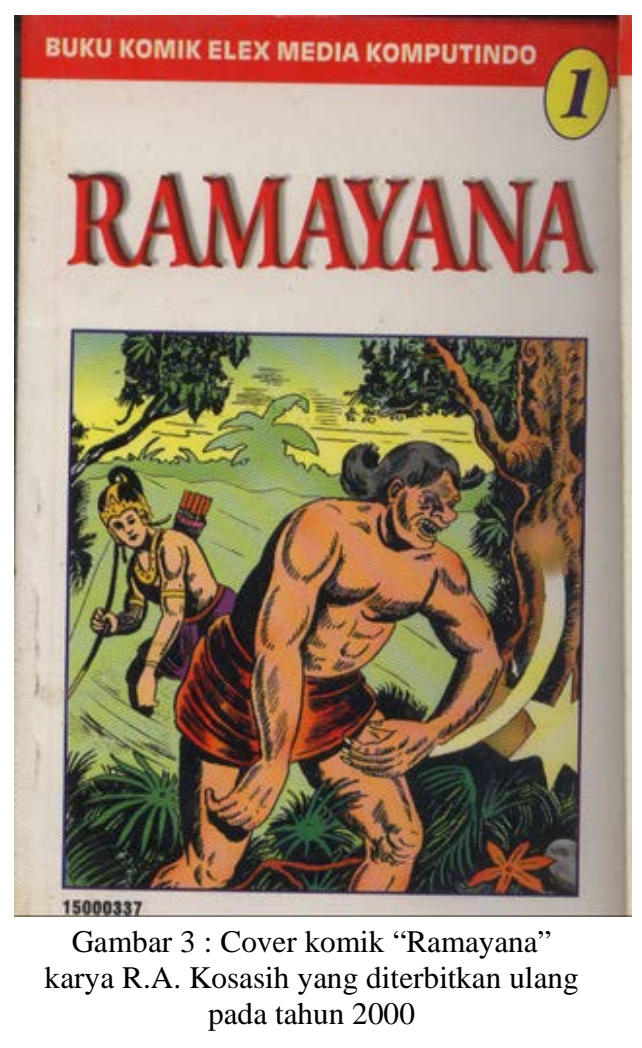

Pada awal dekade 2000, komik wayang yang dulu pernah berjaya sempat diterbitkan kembali seperti Mahabharata dan Ramayana karya R.A. Kosasih. Namun, seperti dikutip pada kata pengantar pada buku katalog Festival Komik Indonesia Satu Dekade (Suroto, 2007), sebagian mengalami perubahan format dan teks. Prestasi penjualan komik-komik cetak ulang ini tidaklah sehebat masa keemasan mereka. Pembelinya semakin segmented, dan ini makin sulit mengingat biaya produksi yang tidaklah murah. Sulitnya melacak gambar master membuat kualitas komik cetak ulang kurang prima. Ini disebabkan karena komik cetakan dengan kertas dan tinta yang tidak bagus, yang dijadikan sumber utama komik cetak ulang. Kendala lain masih berkisar simpang siurnya pemilik hak cipta judul komik, mengingat pada masa lalu tidak banyak transaksi antara komikus dan penerbit terdokumentasi dengan tertib.

Penyesuaian lainnya tampak pada gaya gambar komikus yang dipengaruhi komik terjemahan luar dan keinginan pasar. Dimana dahulu kebanyakan komikus terinspirasi 
gaya realis komik Amerika dan kartun Eropa. Maka menurut Suroto, dekade 90-an menjadi saksi gelombang tsunami komik terjemahan Jepang.

Etalase toko buku pada era sekarang ini dipenuhi komik terjemahan Jepang, sementara komik Amerika dan Eropa yang dahulu berjaya di dekade 70 dan 80-an tersisih di pojokan. Keinginan pasar lah yang menyebabkan fenomena itu terjadi. Komikus lokal era sekarang yang tumbuh berkembang dengan membaca komik Jepang atau disebut manga ikut terpengaruh dalam gaya gambar, sudut pandang dan penyampaian ala manga.

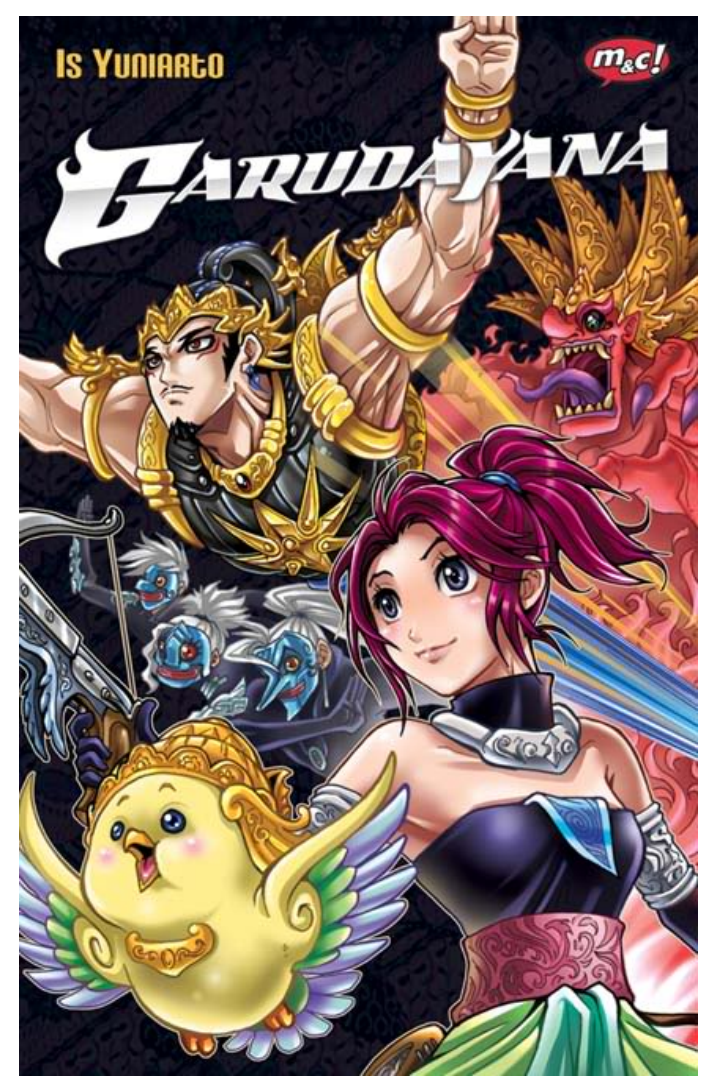

Gambar 4 : Cover komik “Garudayana” karya Is Yuniarto.
Ambil contoh Garudayana karya Is Yuniarto, komikus muda Indonesia yang berhasil menerobos dominasi komik impor karya mangaka-mangaka (sebutan komikus manga Jepang) Jepang. Garudayana yang mengambil tema cerita Mahabharata dianggap berhasil dalam strateginya, cerita klasik pewayangan dengan gaya gambar manga yang sesuai keinginan pasar.

Pemilihan strategi itu tak lepas dari kegundahan Is Yuniarto sendiri yang tertuang dalam akun deviantart miliknya (www.deviantart. com/vanguard-zero). Dimana hal yang menjadi dilema adalah kekhawatiran Is akan stigma negatif terhadap komik Indonesia, terhadap komikus dengan nama Indonesia, dan terhadap tema 'wayang'

yang dianggap kuno. Lebih lanjut lagi, tujuan Is membuat komik Garudayana adalah ingin berbagi dengan pembaca yang lebih muda, tentang pengalaman masa kecilnya, ketika menikmati bagaimana serunya komik wayang jaman dulu. Is menginginkan berbagi pengalaman dunia wayang dengan gaya dan ekspresi berkomiknya dalam gaya pop manga. 
Dari pemaparan di atas, bisa disimpulkan bahwa komik wayang mengalami evolusi dari segi gaya gambar dan penyampaian. Dimana sebelumnya terinspirasi oleh komik Amerika yang cenderung realis, menjadi bergaya manga Jepang yang lebih disukai pasar sekarang ini. Karena bagaimanapun komikus itu manusia yang bercerita, seperti pendapat Scott Mc Cloud (McCloud , 2007:8), selalu menginginkan dua hal dari pemirsa, kita ingin mereka memahami cerita kita dan kita ingin mereka mendengarkan sampai cerita selesai.

Namun, suka atau tidak, evolusi pada komik wayang adalah hasil dari proses seleksi alam dalam dunia penerbitan komik. Dimana hasilnya adalah karya yang paling banyak diminati oleh pembaca dan paling menguntungkan penerbit. Paling tidak, itulah upaya para komikus lokal untuk melestarikan cerita wayang yang merupakan budaya warisan leluhur yang adiluhung.

\section{Dari Komik Kembali ke Wayang}

Bagaimanapun sebuah komik adalah sebuah karya seni. Seperti juga dalam lukisan, kesusasteraan, teater, film, patung, atau bentuk-bentuk seni lainnya (McCloud, 2001:169). Sehingga perlu dihargai eksistensinya dalam menyampaikan informasi dan/atau mencapai tanggapan estetis dari pembacanya (McCloud, 2011:9)

Komik sejatinya bisa digunakan sebagai media penyampai pesan yang efektif. Penggunaan gambar memungkinkan pesan yang akan disampaikan menjadi lebih jelas diterima karena bahasa gambar menjadi lebih mudah dimengerti dibandingkan bahasa tulis atau lisan. Apabila ketiga sarana komunikasi tersebut digabungkan, maka bisa dibayangkan keampuhannya (Kusrianto,2007:164). Komik juga dapat memiliki dua fungsi sekaligus. Pertama, fungsi hiburan, dan kedua, dapat dimanfaatkan secara langsung atau tak langsung untuk tujuan edukatif (Bonneff,1998:67).

Dari paparan tersebut, tak diragukan jika komik merupakan sebuah karya seni yang cukup pantas sabagai wadah cerita pewayangan yang adiluhung. Namun juga, posisinya sebagai budaya pop, membuatnya diminati oleh generasi muda. Dari sini tongkat estefet cerita pewayangan kepada generasi muda dapat dengan mudah tersampaikan. 
Jika sudah demikian, maka akan timbul hubungan dimana pembaca bisa merasakan secara langsung gagasan (McCloud, 2001 :172) komik tersebut. Hal tersebut menimbulkan sikap apresiasi generasi muda terhadap wayang. Selanjutnya pembaca komik wayang akan berusaha mencari tahu dengan lebih mendalam akan gagasan utama dari komik wayang tersebut - yang merujuk pada pagelaran wayang klasik, wayang kulit, wayang golek, dan wayang orang. Maka menjadi tanggung jawab pendidikan - terutama pendidikan seni - untuk menjawab minat generasi muda yang mengapresiasi wayang tadi.

\section{Daftar Rujukan}

Atmowiloto, Arswendo. Wayang Itu Komik. Majalah Tempo edisi 24, 31 Agustus 2009

Bonneff, Marcel. 1998. Komik Indonesia. Jakarta : Kepustakaan Populer Gramedia http://id.wikipedia.org/wiki/Wayang, diakses tanggal 28 Februari 2011 http://www.deviantart.com/vanguard-zero, diakses tanggal 3 Maret 2011 http://www.tokohindonesia.com/biografi/article/285-ensiklopedi/2653-bapak-komikindonesia, diakses tanggal 28 Februari 2011.

Kosasih, R.A. 2000. Ramayana. Jakarta : PT Elex Media Komputindo

Kusrianto, Adi. 2007. Pengantar Desain Komunikasi Visual. Yogyakarta : Penerbit Andi.

McCloud, Scott. 2001. Understanding Comic (Memahami Komik). Jakarta : Kepustakaan Populer Gramedia.

McCloud, Scott. 2007. Making Comic (Membuat Komik). Jakarta : Kepustakaan Populer Gramedia.

Pujanto, Amin. Evolusi Wayang. National Geographic Indonesia edisi April 2009

Suroto, Surjorimba. 90 Tahun RA Kosasih: Bapak Komik Indonesia. Koran Tempo, suplemen Ruang Baca, 26 April 2009

Suroto, Surjorimba. Kata Pengantar Festival Komik Indonesia Satu Dekade. Buku Katalog Festival Komik Indonesia Satu Dekade (1997-2007). Bentara Budaya Jakarta, 9-18 Agustus 2007

Yuniarto, Is. 2009. Garudayana. Jakarta : m\&c! Publishing 


\section{Biodata Penulis}

Dhevi EIR Mahelingga menyelesaikan kuliah Komunikasi Visual, Jurusan Seni dan Desain, Fakultas Sastra, Universitas Negeri Malang pada 2010. Saat ini bekerja sebagai freelancer desain komunikasi visual dan pengajar desain grafis. 